\title{
Judgementoring and how to avert it: Introducing ONSIDE Mentoring for beginning teachers
}

\author{
Andrew J. Hobson
}

Education Research Centre, University of Brighton, UK

\begin{abstract}
Purpose - The purpose of this article is twofold: first, to extend existing knowledge on the nature, reach, causes and consequences of judgementoring; second, to present a new framework for mentoring beginner teachers that has the potential to forestall and combat judgementoring, and enable the full potential of institution-based mentoring to be realised.

Design/methodology/approach - The article draws on a thematic analysis of: previously published findings from three empirical studies undertaken between 2003-2015; new data from two empirical studies undertaken between 2012-16; and recent literature (2013-16) on judgementoring.

Findings - The article provides further evidence of the nature, reach, causes and consequences of judgementoring as a national and international phenomenon. In doing so, it extends previous knowledge about the conditions that enhance or detract from the successful enactment of beginner teacher mentoring.

Practical implications - The findings presented have implications for the work of education policymakers, school and college leaders, mentor trainers, mentors and others concerned with enhancing mentorship and effectively supporting the professional learning, development and wellbeing of beginning teachers.
\end{abstract}

Originality/value - The article presents ONSIDE Mentoring as an original, research-informed framework for mentoring beginner teachers. The framework may also be applicable to other contexts, especially for the mentoring of early career professionals.

Keywords judgementoring, ONSIDE Mentoring, developmental mentoring, teacher education, beginning teacher

Paper type Research paper 
Author Accepted Manuscript, 15 April 2016: Hobson, A.J. (2016), “Judgementoring and how to avert it: Introducing ONSIDE Mentoring for beginning teachers" International Journal of Mentoring and Coaching in Education, Vol. 5 No. 2, pp. 87-110.

\section{Introduction}

Drawing on empirical studies conducted in England and on international research evidence, this article examines institution-based mentoring of beginner teachers in the context of primary and secondary (K-12) schools and post-compulsory education. It focuses, in particular, on the nature, reach, causes and consequences of the phenomenon of judgementoring (Hobson and Malderez, 2013), an enactment of mentoring found to be detrimental to beginner teachers' professional learning, development and well-being. An original, research-informed framework for mentoring, which I call ONSIDE Mentoring, is offered as a means of forestalling or combatting judgementoring, and of enhancing mentoring practice and its positive impact on beginner teachers.

In this article, I use the terms 'beginner' and 'beginning teacher' interchangeably to refer to those undertaking initial teacher preparation ${ }^{1}$ programmes or in their first three years as members of the profession. I define mentoring in this context as

a one-to-one relationship between a relatively inexperienced teacher (the mentee) and a relatively experienced teacher (the mentor), which aims to support the mentee's learning, development and well-being, and their integration into the cultures of both the organisation in which they are employed and the wider profession.

This builds on my own and others' earlier definitions of mentoring (e.g., Malderez, 2001; Hobson et al., 2009a; Hobson and Malderez, 2013) by explicitly including support for mentees' well-being as an essential part of the mentor role. I consider the provision of effective support for beginner teachers' well-being to be of vital importance because the early years of teaching are characterised by intense pressure and sometimes disillusionment (Gold, 1996; Huberman, 1989), and because beginner teachers often report feeling "voiceless", "powerless" and "at the bottom of the pecking order" in their schools and colleges (Hobson, 2009). For these reasons, and others, beginning teachers may generally be regarded as vulnerable learners, as elaborated by Shanks (2014):

The vulnerability of new teachers can be understood as multiple layers of new experiences to deal with - a new profession, perhaps a new location, probably a brand new workplace with new colleagues, new students, continuing assessment and uncertainty as to whether they will obtain a new post for the subsequent school year. New teachers are in a vulnerable situation as a newcomer to their profession while they continue to learn about teaching and

\footnotetext{
${ }^{1}$ The term 'initial teacher preparation' is used to refer to what is variously described as initial teacher education, initial teacher training and 'pre-service' teacher training. My preference for the use of initial teacher preparation has been explained elsewhere (e.g., Hobson et al. 2008).
} 
Author Accepted Manuscript, 15 April 2016: Hobson, A.J. (2016), "Judgementoring and how to avert it: Introducing ONSIDE Mentoring for beginning teachers" International Journal of Mentoring and Coaching in Education, Vol. 5 No. 2, pp. 87-110.

how to be a teacher. (Shanks, 2014, p. 14; cf Kelchtermans and Ballet, 2002; Johnson and Birkeland, 2003)

In addition, higher levels of well-being are associated with increased teacher effectiveness and retention (Day, 2008; Day and Kington, 2008).

Like most published literature on the subject, this article deals with mentoring as a formal arrangement in which individuals are specifically designated to undertake the mentoring role, sometimes within the context of a wider scheme or programme. This is not to suggest that the under-researched practice of informal mentoring is not also an important means of supporting beginner teachers' learning, development and well-being (Tracey et al., 2008).

\section{Research Context}

International research evidence has shown that institution-based mentoring can have a range of powerful, positive impacts on beginning teachers. It has been found, for example, to: help beginner teachers improve their skills of classroom and behaviour management, self-reflection and problemsolving; increase their confidence and self-esteem; and reduce feelings of isolation (Mclntyre and Hagger, 1996; Lindgren, 2005). Largely as a consequence, beginner teachers who are mentored are less likely to leave the profession (Ingersoll and Kralik, 2004). ${ }^{2}$ However, unless appropriate conditions for mentorship are created, mentoring can be ineffectual and even harmful. Hence, some studies have found that mentoring can stunt beginner teachers' professional learning and development (PLD) (Feiman-Nemser et al., 1993; Ling, 2009), bring about anxiety and stress, and contribute to mentees' decisions to leave the profession (Beck and Kosnick, 2000; Maguire, 2001).

What, then, are the conditions in which mentorship is most likely to realise its potential benefits and least likely to have a damaging effect on beginning teachers? Research identifies several common factors associated with efficacious mentoring, ranging from individual- and relationship-level factors through organisational to wider contextual and policy-level considerations.

Firstly, research shows that successful mentoring is partly dependent upon characteristics and traits of individual mentees, including those of openness, willingness to change, and preparedness to operate outside of their comfort zones (Valencic Zuljan and Vogrinc, 2007; Roehrig et al., 2008; Searby, 2014). To the extent that mentees do not already possess such characteristics at the start of a mentoring relationship, their ability to develop them will be influenced by the skills of

\footnotetext{
2 Though a full discussion is beyond the scope of this article, I should add that mentoring has also been found to have a positive impact on mentors, on mentees' and mentors' students and institutions, and on education systems more widely (Hobson et al., 2009a).
} 
Author Accepted Manuscript, 15 April 2016: Hobson, A.J. (2016), “Judgementoring and how to avert it: Introducing ONSIDE Mentoring for beginning teachers" International Journal of Mentoring and Coaching in Education, Vol. 5 No. 2, pp. 87-110.

their individual mentor and the nature and extent of wider institutional and contextual support for mentoring, including various considerations addressed below.

A second and key condition for efficacious mentoring is the existence or development of relational trust between mentees and mentors (D'Souza, 2014; Ng, 2012), partly because this facilitates open and honest discussion $\mathrm{n}$. Whether or not trust can be established is itself dependent on a range of considerations including the skills and dispositions of mentors, whether the mentoring relationship is based on confidentiality, and further contextual considerations discussed below.

Thirdly, researchers have identified common strategies that are employed by mentors in successful mentoring programmes. While, like teaching, mentoring is most successful where it is adapted to the specific support needs and stages of development of individual mentees (Lindgren, 2005), effective mentors typically provide beginner teachers with emotional and psychological support and seek to build their confidence (Hascher et al., 2004), encourage and support their critical interrogation of their own and others' practice (Smith and Ingersoll, 2004), and provide them with appropriate degrees of challenge (Tang, 2003) and autonomy (Valencic Zuljan and Vogrinc, 2007). In addition, several studies (e.g., Heilbronn et al., 2002; Hobson, 2002; Bullough, 2005; Young et al., 2005) report that beginner teachers value mentor 'feedback' on their teaching, including being offered practical strategies for addressing any perceived limitations.

Fourthly, studies have shown that mentoring tends to be more successful when mentors are carefully selected against relevant criteria (Yusko and Feiman-Nemser, 2008) and where care is taken to ensure an appropriate match of mentor and mentee (Wang, 2001). Mentor selection criteria typically include both professional considerations such as being able to exemplify effective practice and possessing excellent subject knowledge (Foster, 1999), and personal characteristics such as empathy, trustworthiness and approachability (Abell et al., 1995), as well as a commitment to mentoring and to their own and others' PLD (Lindgren, 2005). Research has found mentoring to be more beneficial to beginner teachers when they are paired with mentors who teach (or taught) the same age-phase and/or subject or vocational specialism as themselves (Hobson et al., 2007; Smith and Ingersoll, 2004), which importantly also helps to ensure that the mentor has credibility with the mentee (Lejonberg et al., 2015).

A fifth condition for effective mentoring relates to mentors being able to take advantage of appropriate opportunities for initial mentor preparation (Lejonberg et al., 2015), and ongoing development (Bullough, 2005). Such opportunities may include a focus on helping mentors develop their interpersonal skills (Rippon and Martin, 2006) and their ability to facilitate mentees' critical 
Author Accepted Manuscript, 15 April 2016: Hobson, A.J. (2016), “Judgementoring and how to avert it: Introducing ONSIDE Mentoring for beginning teachers" International Journal of Mentoring and Coaching in Education, Vol. 5 No. 2, pp. 87-110.

reflection (Crasborn et al., 2008), and on the potential benefits of discussing pedagogical issues with mentees (Lindgren, 2005).

A sixth key consideration is that mentoring is more effective where there is regular and sustained contact between mentor and mentee, which is facilitated where institutions provide mentors with dedicated time in which to undertake the mentoring role, and where there is timetabled provision that enables mentors and mentees to meet together during the school or college day (Bullough, 2005; Lee and Feng, 2007).

A seventh factor is that some research has found that mentors tend to be more committed to mentorship, and thus more likely to be effective, where they receive financial recognition for undertaking the role and/or where being a mentor contributes to their status or prestige as teachers (Evans and Abbott, 1997; Lee and Feng, 2007). Research has also found that, in a range of education and other contexts, the potential success of institutional mentoring is enhanced through the provision of a mentoring coordinator role, where role-holders tend to be centrally involved in mentor selection, pairing and development, in acting as a central point of contact for mentees, and in monitoring interaction between mentors and mentees and intervening where appropriate (Malderez and Bodoczky, 1999; Kochan et al., 2015).

Several of the considerations outlined above relate to a more general condition for effective mentorship, namely the existence of institutional support for and resourcing of mentoring. Mentoring tends to be more effective where it takes place in institutions that possess collegial learning environments (Lee and Feng, 2007) and in contexts which are relatively free from excessive emphases on externally prescribed goals and agendas such as those relating to teaching practices and teacher assessment (Edwards, 1998). The extent to which institutions are able to provide such a supportive 'architecture' for mentoring (Cunningham, 2007) is influenced by local, state or national government policy and funding.

One question on which researchers have not reached a consensus relates to the issue of whether mentors may be assigned to what some regard as conflicting roles. Hence, several studies (e.g., Heilbronn et al., 2002; Bradbury and Koballa, 2008; Ng, 2012) have indicated that mentoring has greater potential for success when mentors do not line manage and are not involved in formally assessing, evaluating or appraising the work of their mentees. On the other hand, some researchers (e.g., Adey, 1997; Foster, 1999; Yusko and Feiman-Nemser, 2008) have challenged aspects of this position and argued that good mentors can effectively balance support, development and formal evaluation roles. I return to this moot point below. 
Author Accepted Manuscript, 15 April 2016: Hobson, A.J. (2016), “Judgementoring and how to avert it: Introducing ONSIDE Mentoring for beginning teachers" International Journal of Mentoring and Coaching in Education, Vol. 5 No. 2, pp. 87-110.

In our 2013 article published in this journal, Angi Malderez and I argued that failures at institutional and policy levels in England to provide and enable some of the above conditions for effective mentorship contributed to inappropriate enactments of mentoring which stunted the learning and development and had a deleterious effect on the well-being of some beginner teachers. In particular, we highlighted a pathology of mentoring practice that we termed 'judgementoring' and defined as

a one to one relationship between a relatively inexperienced teacher (the mentee) and a relatively experienced one (the mentor) in which the latter, in revealing too readily and/or too often her/his own judgements on or evaluations of the mentee's planning and teaching (e.g. through 'comments', 'feedback', advice, praise or criticism), compromises the mentoring relationship and its potential benefits. (Hobson and Malderez, 2013, p. 90)

In this article, I provide new evidence from the UK and other international contexts on the reach, causes and consequences of judgementoring. I then suggest a number of ways in which judgementoring might be forestalled or combatted, and the full potential of mentoring for beginner teachers realised, including the application of a new framework for mentoring beginning teachers, which I call ONSIDE Mentoring. First, I outline the research underpinning these analyses and discussions.

\section{Methods}

The findings and new mentoring framework presented in this article are informed by analyses of data generated from five empirical studies of mentoring and PLD conducted between 2003 and 2015 , together with a review of international research evidence and personal communications on the phenomenon of judgementoring. The empirical studies are:

- Project 1: The mixed method Becoming a Teacher project, which explored the nature and impact of teachers' experience of initial teacher preparation, induction and early professional development in England (Hobson et al., 2009b);

- Project 2: The mixed method Modes of Mentoring and Coaching project, which investigated the nature and impact of 'external' mentoring and coaching ${ }^{3}$ associated with three national support programmes for teachers of science in England (Hobson et al., 2012);

\footnotetext{
${ }^{3}$ While I regard coaching as one of a number of aspects of a broader mentoring role, and one which relates to attempts to support an individual's development of one or more job-specific skills or capabilities (Malderez and Bodoczky, 1999; Hopkins-Thompson, 2000), others use coaching more broadly and in such a way that
} 
Author Accepted Manuscript, 15 April 2016: Hobson, A.J. (2016), “Judgementoring and how to avert it: Introducing ONSIDE Mentoring for beginning teachers" International Journal of Mentoring and Coaching in Education, Vol. 5 No. 2, pp. 87-110.

- Project 3: A mixed method study of Mentoring and Coaching for Teachers in the Further Education and Skills (FE) Sector ${ }^{4}$ in England, which examined the nature and impact of institution-based mentoring and the potential for external mentoring (Hobson et al., 2015);

- Project 4: A previously unpublished evaluation of an External Mentoring Pilot Project for trainee and qualified teachers of secondary English, developed and implemented at a university in the north of England, in partnership with local schools (2012-13);

- Project 5: The Mentoring Across Professions study, which sought to explore what teacher mentoring can learn from the successful enactment of mentoring and coaching for employees in a range of sectors and international contexts (Hobson et al., 2016).

A summary overview of the methods of data generation and sample sizes for the five empirical studies is provided in Table $1 .{ }^{5}$ All five studies received institutional ethics approval. Data were generated and stored, and findings have been presented in accordance with the ethical guidelines of the British Education Research Association (BERA, 2011).

I should highlight the fact that while this article deals primarily with support provided to beginning teachers by institution-based mentors, the primary focus of two of the five studies (Projects 2 and 4) was on support provided to teachers by 'external mentors' (i.e., mentors not employed within the same institutions as the teachers they were supporting). This apparent anomaly is a major strength of the study, as beginner teacher participants in Projects 2 and 4 were in the relatively unique position of having recently experienced both external and institutional mentoring and, in comparing those experiences, provided some of the most illuminating and powerful data generated to date on school- and college-based mentoring. I should stress too that Project 5 did not seek to study beginner (or other) teachers' experiences of mentoring at all, but rather to provide insights into effective mentoring practice in other sectors and professional contexts. The data generated from Project 5 provided valuable points of comparison with those relating to the enactment of beginner teacher mentoring and the contexts within which such

meets the definition of mentoring set out above. It is thus appropriate to include reference to some such literature and related programmes in this article, as it was in the projects underpinning it.

${ }^{4}$ The FE sector in England, also known as the Post-Compulsory or Lifelong Learning sector, is large and diverse. It includes further education colleges, sixth form colleges, private and charitable training providers, adult and community learning providers, work-based learning providers, training departments of major employers, the armed services, the prison service, etc. (Lingfield, 2012).

${ }^{5}$ It should be noted that the original article on judgementoring (Hobson and Malderez, 2013) drew on the analyses of data from Projects 1 and 2, and that, while drawing on an extended number of studies, this article presents some of the same evidence in discussing the nature, consequences and causes of judgementoring. 
Author Accepted Manuscript, 15 April 2016: Hobson, A.J. (2016), “Judgementoring and how to avert it: Introducing ONSIDE Mentoring for beginning teachers" International Journal of Mentoring and Coaching in Education, Vol. 5 No. 2, pp. 87-110.

enactment took place, and were particularly helpful in informing the development of the new ONSIDE Mentoring framework presented in the final section of this article.

The review of literature focused on work published up to 29 February 2016 that cited the original judgementoring article (Hobson and Malderez, 2013). This included 29 sources listed in Google Scholar. I added an article I co-authored that reports findings from a case study of mentoring provision in an FE college in-service teacher training programme in England (Manning and Hobson, forthcoming). Finally, I also analysed personal communications I had received on the subject of judgementoring from six researchers outside of the UK. These communications took place via the media of email and ResearchGate. ${ }^{6}$

\section{Table 1 - The five empirical research projects examined}

\begin{tabular}{|c|c|c|}
\hline \multicolumn{2}{|r|}{ Research project } & Methods of data generation and achieved samples \\
\hline Project 1 & $\begin{array}{l}\text { The Becoming a Teacher project } \\
\text { (2003-2009) }\end{array}$ & $\begin{array}{l}\text { Annual part-structured interviews (Hobson and Townsend, 2010) } \\
\text { with beginner teachers (BTs) in primary and secondary schools } \\
\text { across England at the end of their initial teacher preparation } \\
\text { (ITP) ( } n=79 \text { ), first ( } n=73 \text { ), second ( } n=64 \text { ) and third ( } n=56 \text { ) years in } \\
\text { post. } \\
\text { Regular email exchanges with BTs in the above interview sample } \\
\text { (46 BTs during their first year in post, } 45 \text { during their second year } \\
\text { and } 36 \text { during their third year). } \\
\text { Annual surveys with BTs in primary and secondary schools across } \\
\text { England at the end of their ITP ( } n=3162 \text { ), first year ( } n=2446 \text { ), } \\
\text { second year ( } n=1973 \text { ) and third year ( } n=1638 \text { ) in post. } \\
\text { Part-structured interviews with } 15 \text { school-based ITP mentors and } \\
27 \text { school-based induction mentors in primary and secondary } \\
\text { schools across England. }\end{array}$ \\
\hline Project 2 & $\begin{array}{l}\text { The Modes of Mentoring and } \\
\text { Coaching project (2010-12) }\end{array}$ & $\begin{array}{l}\text { Part-structured interviews with } 28 \text { (secondary science) BTs } \\
\text { across England who had experienced both institution-based and } \\
\text { external mentoring, and with } 13 \text { external mentors. }\end{array}$ \\
\hline Project 3 & $\begin{array}{l}\text { Mentoring and Coaching for } \\
\text { Teachers in the FE Sector in England } \\
(2014-15)\end{array}$ & $\begin{array}{l}\text { Part-structured interviews with } 40 \text { participants (including } 8 \text { BT } \\
\text { mentees, } 8 \text { mentors and other stakeholders with a knowledge of } \\
\text { mentoring and coaching) across } 19 \text { FE providers. } \\
\text { Online survey completed by } 392 \text { FE teachers and lecturers across } \\
\text { England, } 94 \text { of whom were BTs. }\end{array}$ \\
\hline Project 4 & $\begin{array}{l}\text { The External Mentoring Pilot Project } \\
(2012-13)\end{array}$ & $\begin{array}{l}\text { Open-ended survey with } 8 \text { BTs located in } 3 \text { different schools in } \\
\text { the North of England. } \\
\text { Two focus groups involving a total of } 6 \text { BTs. }\end{array}$ \\
\hline Project 5 & $\begin{array}{l}\text { The Mentoring Across Professions } \\
\text { study (2015-16) }\end{array}$ & $\begin{array}{l}32 \text { interviews and documentary analysis relating to } 10 \text { exemplary } \\
\text { mentoring and coaching schemes across six countries. }\end{array}$ \\
\hline
\end{tabular}

*This table does not list all data relating to each project; only data relevant to the current study.

\footnotetext{
${ }^{6}$ ResearchGate is a social networking site in which academics share research outputs, ask and answer questions, and find collaborators. For further information, see researchgate.net
} 
Author Accepted Manuscript, 15 April 2016: Hobson, A.J. (2016), “Judgementoring and how to avert it: Introducing ONSIDE Mentoring for beginning teachers" International Journal of Mentoring and Coaching in Education, Vol. 5 No. 2, pp. 87-110.

\section{Analytical framework}

A thematic analysis (Braun and Clarke, 2006) was undertaken of: previously published findings from Projects $1-3 ;{ }^{7}$ new data generated for Projects 4-5; all publications retrieved as part of the literature review; and the personal communications. The analysis was informed by the following research questions:

1) How prevalent is judgementoring in the UK and in other international contexts?

2) What are the apparent consequences and causes of judgementoring?

3) What are the key features of mentoring programmes and relationships that might forestall judgementoring and be embedded in a new framework for mentoring beginning teachers?

The outcomes of these analyses are now presented below.

\section{Findings}

\section{The nature and reach of judgementoring}

In 2013, Malderez and I identified judgementoring as an inappropriate enactment of mentoring on the grounds that mentors were explicitly evaluative and judgemental and practised an unnecessarily directive form of mentoring. We suggested that many mentors were (over) reliant on the strategy of observing and providing mentor-led 'feedback' on mentees' lessons. We also showed that, in some cases, mentees experienced such feedback - and sometimes mentors' dealings with them more generally - as unduly critical and negative:

[My mentor] would go 'this went very well but', and then he seemed to focus dreadfully on the things that hadn't gone so well." (Mentee, Project 1)

[W] hatever you ask your mentor they would judge you on and [think] 'why doesn't she know that?' (Mentee, Project 2)

While in our 2013 paper Malderez and I noted that our data precluded us from estimating the prevalence of judgementoring within and beyond schools in England, others have since testified to its existence in the UK and further afield. Firstly, for example, in their study of mentoring in initial teacher preparation in England, Lofthouse and Thomas (2014) conclude that:

\footnotetext{
${ }^{7}$ Twelve publications (selected research reports and peer reviewed journal articles) were reviewed for this aspect of the study. The reviewed publications are denoted with an asterisk in the Reference section of this article.
} 
Author Accepted Manuscript, 15 April 2016: Hobson, A.J. (2016), “Judgementoring and how to avert it: Introducing ONSIDE Mentoring for beginning teachers" International Journal of Mentoring and Coaching in Education, Vol. 5 No. 2, pp. 87-110.

The trend towards the practice of judgementoring ... is illustrated through this case study, with students feeling judged against standards from very early in their school placements. (Lofthouse and Thomas, 2014, p. 215).

Secondly, Duckworth and Maxwell (2015) state that their review of literature on mentoring in teacher training programmes in the FE sector in England "demonstrates the prevalence of a "judgementoring" approach" (p. 17). This conclusion is supported by the findings of Project 3 , in which the following viewpoint expressed by a beginner teacher who had worked with a number of mentors was not uncommon:

[The mentor's role is] first of all to identify weaknesses of the ... teacher, and then develop a plan of action addressing the weak points. (Mentee, Project 3)

And, in a case study of an FE college in-service teacher training programme on the south coast of England, Manning and Hobson (forthcoming) provide further triangulated evidence, drawn from observations of mentoring conversations as well as interviews with mentors and mentees, of judgemental and directive approaches to mentoring as well as the less frequent use by some mentors of more developmental and non-directive (Clutterbuck, 1992; 2004) approaches. The study elaborates on the enactment of judgemental mentoring by detailing how mentors tend to set the agenda for meetings, lead discussion around their own evaluations of mentees' lessons, and provide strong advice in a relatively directive fashion.

Other researchers suggest that judgementoring exists to some degree in a range of other international contexts. Firstly, in the US: D'Souza (2014) shows that beginning teachers reflected on how the development of trusting relationships with members of a research team compared favourably with mentoring relationships, characterised by one participant as "you meet, they watch you teach and give you feedback. They are looking for some kind of deficit" (p. 179); and Lunsford (2016, personal communication) notes that "we found exactly this [judgementoring] in border schools in Arizona." Secondly, in Norway, Lejonberg et al. (2015) report that some mentors in their study expressed "beliefs consistent with judgementoring (evaluative or judgemental mentoring)" ( $p$. 142), notably about the importance of mentees hearing their (mentors') evaluations of mentees' teaching. Thirdly, in a national study of mentoring in early childhood education services and schools in New Zealand, Cameron et al. (2014, pp. 65-66) report "examples of feedback that reflected what Hobson and Malderez (2013, p. 90) describe as 'judgementoring'". Fourthly, Kourieos (2015, personal communication) noted that the description of judgementoring in the original article 
Author Accepted Manuscript, 15 April 2016: Hobson, A.J. (2016), “Judgementoring and how to avert it: Introducing ONSIDE Mentoring for beginning teachers" International Journal of Mentoring and Coaching in Education, Vol. 5 No. 2, pp. 87-110.

(Hobson and Malderez, 2013) was "so familiar to my own context", namely pre-service language teacher education in Cyprus.

\section{Consequences of judgementoring}

It is clear from my own and others' research that the practice of judgementoring impedes the development of safe and trusting relationships between mentors and mentees, and that this is detrimental to mentees' PLD insofar as it results in beginner teachers:

1) being reluctant to seek the support of a mentor because, for example:

In the current climate, the wrong sort of head might use this as evidence that I wasn't performing adequately. (Mentee, Project 2)

2) refraining from being open and honest with mentors about their perceived PLD needs, which has been termed 'fabrication as strategic silence' (Hobson and McIntyre, 2013);

Irrelevant of how wonderful and positive school based support and guidance is, there are always agendas and judgements attached - which restrict my willingness to share hopes, fears, concerns, ambitions. (Mentee, Project 4)

3) avoiding forms of behaviour and interaction that they fear may draw attention to perceived weaknesses in their teaching capability or gaps in their knowledge, which has been termed 'fabrication as strategic avoidance' (Hobson and McIntyre, 2013).

Fabrication as strategic avoidance may involve mentees discouraging mentors and/or others from observing them teach classes they find difficult to manage, ignoring or failing to report problematic pupil behaviour, or as one beginner teacher put it, deliberately "putting subject knowledge to the back" (Mentee, Project 2). Putting subject knowledge to the back meant focusing, in their planning and teaching, on aspects of the curriculum about which beginner teachers felt confident, to avoid being asked awkward questions on aspects about which they felt less confident:

In terms of planning, the kids will ask you a question, something about physics and you're hoping no one will ask you. (Mentee, Project 2)

Judgementoring can impede beginner teachers' PLD in other ways, too. The relatively directive nature of judgementoring and the associated lack of autonomy that it affords to mentees can result in an overreliance on mentors and impede the development of the important skills of critical reflection in and on practice (Schön, 1983) and of what Claxton (2004) terms 'learnacy' defined in this context as a mentees' ability to manage their ongoing learning from their own and 
Author Accepted Manuscript, 15 April 2016: Hobson, A.J. (2016), “Judgementoring and how to avert it: Introducing ONSIDE Mentoring for beginning teachers" International Journal of Mentoring and Coaching in Education, Vol. 5 No. 2, pp. 87-110.

others' experiences of teaching (Malderez, 2015). Hence, Cameron et al. (2014) note that examples of judgementoring found in their New Zealand study led to mentees "relying on mentor judgements" at the expense of "think[ing] critically about their own practice" (p. 66).

Judgementoring can also impede beginner teachers' well-being. In our original study, Malderez and I noted that some such mentees who encountered judgementors described themselves as "disheartened", "demoralised", "isolated" or "lonely". Similarly, Lofthouse and Thomas (2014) quote one student teacher who talked about "getting disheartened about things you've done" as a result of mentors "judging you" (p. 211). Related to this, beginner teachers' experiences of judgementoring can also contribute to their decisions to discontinue initial teacher preparation, or leave the profession. Indeed, an analysis of data from the Becoming a Teacher project (Project 1 ) revealed that a common factor identified by student teachers who withdrew from initial teacher preparation programmes was poor relationships with mentors, and the receipt of mentor feedback that they regarded as unduly negative and critical (Chambers et al., 2010; Hobson et al., 2009c).

\section{Causes of judgementoring}

My analyses suggest that there are four broad and somewhat interconnected causes of judgementoring. Firstly, the evidence presented above - and the wider evidence and datasets analysed for this study - suggest that a (if not the) major cause is the fact that many and perhaps most schools and colleges who provide beginner teachers with mentors, assign those mentors to the conflicting roles of formally evaluating and assessing the beginner teachers on the one hand, and supporting their PLD on the other. In some cases, the situation is compounded where mentors of beginner teachers are also their line managers or supervisors, a role which necessarily requires formal evaluation of the work of the beginner teacher. It is noteworthy that in the 10 case studies of exemplary work-based mentoring and coaching schemes undertaken for Project 5, which found no evidence of judgementoring, mentoring and coaching were exclusively 'off-line' (i.e., separated from mentees' line-management/supervision) and mentors and coaches had no involvement in the formal evaluation of their mentees' performance. The Mentoring Scheme Induction Brochure of one of the 10 case studies - the English Football Association Referee Mentoring Scheme - explicitly addresses the rationale for the mentoring being off-line in stating that this

enables a more fully open relationship between mentor and referee and prevents the mentor from having a conflict of roles. (Football Association, 2014, p. 4) 
Author Accepted Manuscript, 15 April 2016: Hobson, A.J. (2016), “Judgementoring and how to avert it: Introducing ONSIDE Mentoring for beginning teachers" International Journal of Mentoring and Coaching in Education, Vol. 5 No. 2, pp. 87-110.

And some of the ways in which 'on-line' mentoring would compromise the mentoring relationship are explained by a senior police officer interviewed for another Project 5 case study:

There's no way l'd want to be mentored or coached by my line manager ... because you're so vulnerable when you're in coaching in terms of, for example, I might know deep down that I've got a weakness that I'm hoping that I can sort out, but if I tell my line manager about that it's going to be in my next appraisal because they're suddenly aware of it ... So, you know, it doesn't work and if something's happened with a colleague or someone's really annoyed you and you're telling your line manager, you're putting them in a position where they've almost got to act. (Coachee, Project 5)

A second (and related) contributory factor to the enactment of judgementoring is particularly apparent in the data generated for Project 3 (mentoring in the FE sector in England). This study shows that, apart from allocating mentors to trainee and newly qualified teachers, which is standard practice, many institutions selectively employ mentoring or coaching as a remedial strategy to address perceived under-performance rather than enabling all teachers to access mentoring support for their PLD. Interviewees explained that, in some such institutions, teachers and lecturers are allocated a mentor or coach where their teaching is judged through lesson observations to be Grade 3 ('requires improvement') or 4 ('inadequate') in Ofsted terms. ${ }^{8}$ In such a scenario, beginning and more experienced teachers will naturally associate mentoring with evaluations of and judgements on their teaching. Furthermore, such a scenario encourages a stigma to be attached to being mentored, which is likely to exacerbate the tendency toward fabrication as strategic silence and strategic avoidance, as the following excerpt from an interview with an FE college's head of professional development suggests:

I remember this woman recounting a story of going into the staffroom as a coach to work with someone and people there going 'Oh, have they come to pick me?' ... So it's actually [perceived to be] a bad thing. You know, it means you're doing something wrong if you're working with a mentor or working with a coach. (Project 3)

The third broad cause of judgementoring relates to the wider policy and cultural context within which mentoring in schools and colleges is situated. On the one hand, in some education systems, the practice at institutional level of involving mentors in the formal assessment and

\footnotetext{
${ }^{8}$ Ofsted (The Office for Standards in Education, Children's Services and Skills) is the non-ministerial department of the UK government that inspects and regulates services that care for children and young people, and services providing education and skills for learners of all ages in England, most notably schools.
} 
Author Accepted Manuscript, 15 April 2016: Hobson, A.J. (2016), “Judgementoring and how to avert it: Introducing ONSIDE Mentoring for beginning teachers" International Journal of Mentoring and Coaching in Education, Vol. 5 No. 2, pp. 87-110.

evaluation of their mentees' teaching actually reflects policy imperatives. With respect to initial teacher preparation for primary and secondary school teachers in England, Lofthouse and Thomas (2014) note that

The award of [Qualified Teacher Status] is judged by the subject mentor, professional tutor and university tutor as a collective. Thus, mentoring as a practice plays a pivotal role in the workplace learning experience and assessment of student teachers. (Lofthouse and Thomas, 2014, pp. 201-2, emphasis added)

This association of formal assessment and evaluation with mentoring is also established in relation to newly qualified teachers (NQTs - those who have secured 'Qualified Teacher Status') - in the following wording from England's Department for Education's (2015) statutory guidance for schools:

The head teacher/principal must identify a person to act as the NQT's induction tutor, to provide day to day monitoring and support, and co-ordination of assessment. The induction tutor ... should be able to provide effective coaching and mentoring ... [and] review the NQT's progress at frequent intervals throughout the induction period ... NQTs should have formal assessments carried out by either the head teacher/principal or the induction tutor.

(Department for Education, 2015, pp. 16-17; emphasis added)

With regard to the English FE sector, Duckworth and Maxwell (2015) conclude that policy reforms (DfES, 2004) have imposed a model of mentoring that emphasises subject support and the assessment of teaching competence ... and has led to judgemental rather than developmental approaches to mentoring ... aligning with Hobson and Malderez's (2013) conceptualisation of "judgementoring" in the schools sector. (Duckworth and Maxwell, 2015, p. 8)

On the other hand, and less directly, the involvement of mentors and others in routine formal evaluation of the work of beginning teachers (and teachers in general) in England has been encouraged by the government's role in embracing the 'Global Educational Reform Movement' (GERM) (Sahlberg, 2010) and what Ball (2003) refers to as 'the terrors of performativity', which are characterised by government control over the curriculum and workforce, and monitoring and 'inspection' of school, college and teacher effectiveness or 'performance'. Hence, vast amounts of time, energy and resource are committed to preparing for high stakes Ofsted inspection, for example, and, given the very serious consequences of attracting an unfavourable Ofsted grade, school and college leadership teams invariably focus on seeking to bring about an immediate 
Author Accepted Manuscript, 15 April 2016: Hobson, A.J. (2016), “Judgementoring and how to avert it: Introducing ONSIDE Mentoring for beginning teachers" International Journal of Mentoring and Coaching in Education, Vol. 5 No. 2, pp. 87-110.

improvement in teachers' 'performance', as measured against external evaluation criteria, at the expense of a more developmental approach that might better support teachers' ongoing, mediumto longer-term professional learning, development and effectiveness.

While the specific examples cited above are from England, performativity and (by definition) GERM cross national borders and there are indications that an increased emphasis on monitoring and accountability in education is impacting on the mentoring of beginner teachers and others in a range of international contexts. For example, $\mathrm{Ng}$ (2012) notes that while mentoring and coaching in Singapore were "premised on a developmental philosophy", tensions have arisen as mentors and coaches have become deployed "in the critical area of appraisal linked to remuneration and career advancement" (p. 31). Secondly, while mentors in Norway and other Scandinavian countries have generally been able to focus on supporting mentees' PLD without formally assessing them (Ulvik and Sunde, 2013), Lejonberg et al. (2015) note that "mentors sometimes contribute to decisions regarding whether mentees should be hired or not", which "might result in circumstances in which judgementoring is likely to occur" (p. 145). Thirdly, Lunsford (2016, personal communication) notes that "the pressures for testing in the US I feel have really made judgementoring part of the preservice teacher mentoring relationship."

Notwithstanding other likely contributory factors, such as the failure of many schools and colleges to employ sufficiently rigorous methods of mentor selection (based on appropriate selection criteria such as potential to provide non-judgemental support), the fourth major cause of the widespread enactment of judgementoring is the frequent absence (well-established in the mentoring literature) of appropriate provision for mentor education and training. In the absence, in particular, of effective training in the use of non-judgemental and non-directive approaches to mentoring, mentors will inevitably draw upon their own experiences of mentoring as mentees and/or on 'common sense' pedagogical constructs such as 'teaching (or mentoring) is telling' (Tomlinson, 1995). In a study of factors that support and hinder the development of leadership capacity in mentors working with beginner teachers in New Zealand, Thornton (2014) concluded that:

Without in-depth professional learning opportunities, mentors are more likely to revert to telling the beginning teacher what to do or being overly critical, a practice described by Hobson and Malderez (2013) as judgementoring, rather than ensuring the learning is selfdirected, tailored to the individual teacher. (Thornton, 2014, p. 27) 
Author Accepted Manuscript, 15 April 2016: Hobson, A.J. (2016), “Judgementoring and how to avert it: Introducing ONSIDE Mentoring for beginning teachers" International Journal of Mentoring and Coaching in Education, Vol. 5 No. 2, pp. 87-110.

Lejonberg et al.'s (2015) quantitative study in Norway found that where appropriate opportunities for mentor preparation and development are provided, "mentor education contributes to lower reported levels of beliefs consistent with judgementoring" (р. 149).

\section{Discussion: combatting judgementoring}

In this article I have extended earlier work in producing the most comprehensive account to date of the nature, reach, consequences and causes of judgementoring (Hobson and Malderez, 2013). The findings presented substantiate those of some previous studies, and challenge and qualify those of others. For example, the weight of evidence strongly supports the findings of those researchers (e.g., Heilbronn et al., 2002; Bradbury and Koballa, 2008; Ng, 2012) who have concluded that mentoring relationships are more productive and mentoring is more effective where mentors do not line manage/supervise, or have a formal assessment or evaluative role in relation to the work of their mentees, not least because the power dynamics involved tend to impede the development of an open trusting relationship between mentor and mentee (Oberski et al., 1999). I have shown, too, that the much-used mentoring strategy of observing and 'providing feedback' on beginner teachers' lessons, which several studies have reported as being highly valued by mentees, is not at all unproblematic, and I discuss this matter further below.

The evidence of this study seems clear that judgementoring is currently enacted in a range of contexts internationally, to the detriment of beginner teachers' PLD, well-being and retention. I would argue that if they value and have a sense of responsibility toward these vulnerable learners, then policymakers, school and college leaders, mentoring coordinators, mentor trainers and mentors must seek to avoid enacting or encouraging the enactment of judgementoring, and instead seek to maximise the significant potential benefits of mentorship. How might they do so?

Firstly, evidence from Projects 2, 4 and 5 suggests that judgementoring tends to be avoided and that mentoring may generally be more effective where mentors are external to the organisation in which the mentee is employed. In particular, external mentors are more able than institutionbased mentors to provide a safe or 'third space' (McIntyre and Hobson, 2016) within which mentees can openly share their hopes, fears, and perceived limitations without fear of reprisal. The following quotation illustrates the point:

During our NQT year at [school] we work alongside [external mentor] who is employed by the school but is not a member of staff. He is a neutral party and a fantastic source of support and guidance. It is an important part of his role as a mentor that he is not a member of senior leadership. Because of his unbiased standpoint you really feel at the centre of the 
Author Accepted Manuscript, 15 April 2016: Hobson, A.J. (2016), “Judgementoring and how to avert it: Introducing ONSIDE Mentoring for beginning teachers" International Journal of Mentoring and Coaching in Education, Vol. 5 No. 2, pp. 87-110.

process - there are no hidden agendas; it's just about your progress ... By having direct access to a neutral forum I [am] able to communicate professionally without consequence. (Beginner teacher, Project 4)

To what extent it is practicable for schools and colleges to deploy external rather than institutionbased mentors is another matter, and this will depend on the specific context. Nonetheless, I suggest that, at the very least, schools and colleges should seek to appoint external mentors where there are no colleagues within the institution who meet the criteria for mentor selection and matching to a specific beginner teacher, such as where there are no suitable candidates who share the same subject or vocational specialism. ${ }^{9}$

Turning to specific recommendations for policymakers, it should be noted that a common characteristic of the contexts of the 10 case studies of exemplary work-based mentoring and coaching programmes examined in Project 5, in which judgementoring was notable by its absence, was that they were relatively free from external regulation and control. This highlights the fact that in a number of countries, not least my own, national policymakers exert a significant influence over the work of education professionals in general and the monitoring and assessment of teachers' work in particular, with apparently little recourse to the findings of education research. This scenario has contributed to the enactment of judgementoring as well as other terrors of performativity (Ball, 2003). A second set of recommendations then, is to urge policymakers: (1) to reduce the emphasis on the monitoring, observation, assessment and evaluation of teachers' 'performance'; and (2) to reduce their micro-management of education more generally and seek to create a framework within which education policy and practice can become genuinely evidence-informed.

\section{Toward a new framework for mentoring beginner teachers: ONSIDE Mentoring}

Despite the above critique of education policy, and notwithstanding the preponderance of research on teacher mentoring, it might be argued that one of the reasons why policymakers, school and college leaders, and individual mentors have got it so wrong in encouraging and presiding over the terrors of judgementoring, is the lack of a specific research-informed framework for the mentoring of beginning teachers. I conclude this article by offering such a framework - one which is sensitive to the specific needs and vulnerabilities of beginning teachers, which may be used across a range of contexts internationally, and which, if employed, would be likely to restrict the enactment of judgementoring and its undesirable consequences.

\footnotetext{
${ }^{9}$ For more information about external mentoring and its potential benefits for beginner teachers and teachers more generally, see Hobson et al. (2012); Hobson and McIntyre (2013); Mclntyre and Hobson (2016).
} 
Author Accepted Manuscript, 15 April 2016: Hobson, A.J. (2016), “Judgementoring and how to avert it: Introducing ONSIDE Mentoring for beginning teachers" International Journal of Mentoring and Coaching in Education, Vol. 5 No. 2, pp. 87-110.

This new mentoring framework, which I call ONSIDE Mentoring, shares key assumptions and elements with, and extends, a number of other frameworks for and approaches to mentoring, coaching and PLD - most notably:

1) developmental approaches to mentoring (Clutterbuck, 1992; 2004) and reflective practitioner (Schön, 1983) approaches to PLD, which seek to empower mentees and promote their learnacy (Claxton, 2004);

2) growth and compassion-based approaches to mentoring and coaching (Boyatzis et al., 2013; Jack et al., 2013), which assume that mentees and coachees (in this case, beginner teachers) "have the capacity for self-reflection and growth" (Netolicky, 2016); and

3) scaffolding (Wood et al., 1976) - the sociocultural learning metaphor for the contingent (temporary and adjustable) support for an individual's learning and development provided by someone more experienced or adept at what they are seeking to learn or develop.

ONSIDE Mentoring also draws on models of peer mentoring and is sympathetic to Hargreaves and Fullan's (2000) argument that, for various reasons, including developments in the science of teaching ... [and] the spread of information technologies ... [t]he old model of mentoring, where experts who are certain about their craft can pass on its principles to eager novices, no longer applies ... the new teacher may sometimes know more than the mentor about new teaching strategies. If the school assumes the mentor always knows best ... innovative new teachers might quickly experience the mentoring relationship as an oppressive one. (Hargreaves and Fullan, 2000, pp. 52-53)

ONSIDE Mentoring does not assume that the mentor always knows best; rather, it promotes a nonhierarchical learning partnership (Zachary, 2009) that will benefit both mentor and mentee. Nonetheless, while beginner teachers doubtless benefit from participation in peer mentoring with one or more other relative novices (Cornu, 2005; Sorensen and Sears, 2005), ONSIDE Mentoring assumes that there is added value in beginning teachers being mentored by more experienced ones. This is because more experienced teachers are likely to be more able than beginners' immediate peers to effectively undertake some important mentor roles, including those identified by Malderez and Bodocsky (1999) as 'acculturator' (helping mentees into full membership of the professional culture), 'sponsor' (e.g., introducing the mentee to the 'right people') and 'model' (e.g., demonstrating aspects of being a teacher in the specific context). 
Author Accepted Manuscript, 15 April 2016: Hobson, A.J. (2016), “Judgementoring and how to avert it: Introducing ONSIDE Mentoring for beginning teachers" International Journal of Mentoring and Coaching in Education, Vol. 5 No. 2, pp. 87-110.

Turning more explicitly now to what ONSIDE Mentoring involves, it comprises what I consider - based on the research outlined in this article - to be seven imperatives of mentoring relationships. These are set out (and the first six briefly elaborated) in Table 2, which also defines their polar opposites - what mentoring frameworks and relationships should avoid.

\section{Table 2: ONSIDE Mentoring}

\begin{tabular}{|c|c|}
\hline MENTORING IS / SHOULD BE... & MENTORING SHOULD NOT... \\
\hline $\begin{array}{l}\text { ff-line (i.e., separated from line-management or } \\
\text { supervision) and non-hierarchical }\end{array}$ & $\begin{array}{l}\text { Occur within hierarchical and power relationships - } \\
\text { e.g. where mentors formally assess the work of } \\
\text { mentees. This makes it difficult to establish relational } \\
\text { trust and for mentees to openly share their } \\
\text { professional learning and development needs with } \\
\text { mentors. }\end{array}$ \\
\hline Non-evaluative and non-judgemental & $\begin{array}{l}\text { Be evaluative or judgemental, which can also impede } \\
\text { the establishment or maintenance of a trusting } \\
\text { relationship between mentor and mentee, and (partly } \\
\text { in consequence) impede mentees' professional } \\
\text { learning, development and well-being. }\end{array}$ \\
\hline $\begin{array}{l}\text { Supportive of mentees' psychosocial needs and } \\
\text { well-being }\end{array}$ & $\begin{array}{l}\text { Focus solely on mentees' 'performance' or the } \\
\text { development of their capability with no consideration } \\
\text { for mentees' emotional or psychological state or their } \\
\text { well-being. The latter are both important in their own } \\
\text { right and impact on mentees' capacity to learn and } \\
\text { develop. }\end{array}$ \\
\hline $\begin{array}{l}\text { Individualised - tailored to the specific and } \\
\text { changing needs (emotional as well as developmental) } \\
\text { of the mentee }\end{array}$ & $\begin{array}{l}\text { Be one-size-fits-all, since any given mentoring } \\
\text { strategy will be more or less relevant to and produce } \\
\text { different (positive or negative) responses in/from } \\
\text { different mentees. }\end{array}$ \\
\hline $\begin{array}{l}\text { Developmental and growth-oriented - seeking to } \\
\text { promote mentees' learnacy and provide them with } \\
\text { appropriate degrees of challenge }\end{array}$ & $\begin{array}{l}\text { Be solely or selectively deployed as a remedial } \\
\text { strategy to 'correct' perceived deficiencies in } \\
\text { professional practice. This can discourage mentees } \\
\text { from taking advantage of the 'support' of mentors, } \\
\text { and encourage them to fabricate their learning and } \\
\text { development needs. }\end{array}$ \\
\hline $\begin{array}{l}\text { Empowering - progressively non-directive to } \\
\text { support mentees to become more autonomous and } \\
\text { agentic }\end{array}$ & $\begin{array}{l}\text { (Normally) be directive, in which mentors provide } \\
\text { 'solutions' rather than supporting mentees to find } \\
\text { their own, and which accords mentees little } \\
\text { autonomy and agency. This encourages mentees' } \\
\text { dependency on the mentor and does not promote } \\
\text { learnacy. }\end{array}$ \\
\hline
\end{tabular}

The seventh imperative of ONSIDE Mentoring is that, as the mnemonic implies, mentors are first and foremost on the side of - allies, champions and advocates for - their mentees. Beginner teachers' status as vulnerable learners (Shanks, 2014) at the bottom of the pecking order (Hobson, 2009) provides a moral as well as practical imperative that someone takes their side (Becker, 1967; 
Author Accepted Manuscript, 15 April 2016: Hobson, A.J. (2016), “Judgementoring and how to avert it: Introducing ONSIDE Mentoring for beginning teachers" International Journal of Mentoring and Coaching in Education, Vol. 5 No. 2, pp. 87-110.

Gouldner, 1968) and that they are allocated an ally in whom they can place their trust. ONSIDE Mentoring is thus part-predicated on the research-informed assumption that establishing relational trust is pivotal to the success of the mentoring relationship and, therefore, to enhancing mentees' learning, development and well-being. Indeed, the off-line, non-evaluative (and non-judgemental), supportive and individualised (ONSI) elements of ONSIDE Mentoring are all designed to promote the development of relational trust between mentor and mentee.

Importantly, however, being on the mentee's side, winning their trust and supporting their well-being will also sometimes require ONSIDE Mentors to suspend the promotion of certain features of ONSIDE and developmental mentoring. This is because the experience of non-directive forms of mentoring can sometimes be stressful for beginning teachers (especially in the early stages of their field or 'placement' experiences as trainee teachers, or of their first teaching posts as newly qualified teachers), as can the provision of appropriate degrees of challenge that encourage mentees out of their comfort zones (Tang, 2003). In order to support beginner teachers' emotional and psychological needs and well-being, it will therefore sometimes be necessary for mentors to adopt a relatively directive approach and offer them 'practical advice', notably where they appear unable to find their own solutions and/or where the absence of a 'quick fix solution' is considered potentially harmful to beginner teachers themselves or to the students in their care. ONSIDE mentoring is thus progressively non-directive, progressively autonomy-promoting and progressively challenging, seeking to develop mentees' learnacy to the extent that this is consistent with ensuring they are not exposed to too much stress or too many potential impediments to their well-being.

The ONSIDE Mentoring framework is therefore consistent with and extends scholars' use of Wood et al.'s (1976) scaffolding metaphor in the context of mentoring and coaching beginning teachers (e.g., Edwards and Collison, 1996; Collet, 2015) and others. Brown and Palincsar (1986) explain that in supporting learning through scaffolding:

(a) the degree of aid, or scaffolding, is adapted to the learner's current state; (b) the amount of scaffolding decreases as the skill of the learner increases; (c) for a learner at any one skill level, greater assistance is given if task difficulty increases, and vice versa. (Brown and Palincsar, 1986, p. 38).

And Greenfield (1984) notes that scaffolding creates "an environment which reduces ... failure experiences at the early stages of learning a new skill" (p. 119). In line with this, ONSIDE Mentors should: 
Author Accepted Manuscript, 15 April 2016: Hobson, A.J. (2016), “Judgementoring and how to avert it: Introducing ONSIDE Mentoring for beginning teachers" International Journal of Mentoring and Coaching in Education, Vol. 5 No. 2, pp. 87-110.

a) provide sufficient scaffolded support to ensure beginner teachers do not perceive themselves to be failing (which would be detrimental to their well-being), while also seeking to build their confidence (to enhance their well-being);

b) progressively reduce the amount of scaffolding (i.e., make their mentoring increasingly nondirective) in order to accord beginner teachers greater autonomy, responsibility and challenge; and

c) be ready to re-erect some temporary scaffold if and when necessary.

In ONSIDE Mentoring, the erection or temporary re-instatement of scaffolding relates not only to mentees' skill level and to task difficulty (Brown and Palincsar, 1986) but also to their emotional and psychological preparedness for and response to specific experiences as teachers.

Turning to discuss more practical aspects of what ONSIDE Mentors' scaffolded support for beginning teachers might entail, Edwards and Collison (1996) helpfully suggested a number of ways in which mentors may scaffold the learning and development of beginning teachers - and student teachers in particular (to whom they refer below as 'students') - including:

listening to students; modelling teaching and general classroom management; analysing and discussing [their] own practice; observing students; negotiating with students their own learning goals; supporting students while they teach; [and] ... providing constructive criticism. (Edwards and Collison, 1996, pp. 27-28; emphasis added).

I wish to advance this discussion by urging a healthy measure of research-informed caution regarding ONSIDE (indeed any) mentors' use of the strategy of observing and providing constructive criticism (or 'feedback') to beginning teachers, which Edwards and Collison (1996) recommend here and which in some contexts is not merely the most commonly used strategy of mentors but has become almost synonymous with teacher mentoring. As we have seen, several studies (e.g., Heilbronn et al., 2002; Hobson, 2002; Bullough, 2005; Young et al. 2005) have reported that beginner teachers often value this mentoring strategy, and this finding is also apparent in the accounts of beginner teacher participants in Project 1 (Hobson et al., 2009b). Such findings are also consistent with important work conducted in the field of cognitive skill psychology, which emphasises how skill acquisition can be assisted through coaching. Sloboda (1986) noted that "[r]eal life skills ... are usually learnt with the aid of some form of coaching", and argued that appropriate 
Author Accepted Manuscript, 15 April 2016: Hobson, A.J. (2016), “Judgementoring and how to avert it: Introducing ONSIDE Mentoring for beginning teachers" International Journal of Mentoring and Coaching in Education, Vol. 5 No. 2, pp. 87-110.

feedback on practice or "knowledge of what your actions achieved", is "essential to skill acquisition" (pp. 32-33). Developing the point, Tomlinson (1998) states that

the acquisition of practical capability requires cycles of plan-attempt-feedback-replan, a process which when done with the same action unit tends to produce a gradual tuning ... that makes it more accurate, economical and intuitive. (Tomlinson, 1998, p. 13)

However, the present study also emphasises that, for some beginning teachers, the anticipation and subsequent experience of having their teaching observed and 'receiving' post-lesson feedback or 'constructive criticism' from others can:

1) be potentially damaging to the development or maintenance of open, trusting relationships between observers and observed - especially where beginner teachers feel that their teaching is (or they as individuals are) being evaluated and 'judged';

2) potentially impede their development of autonomy and learnacy and make them dependent on the observer, where the observer is too directive and provides too much 'practical advice'; and

3) be potentially stressful, as the following quotation illustrates:

[Lesson] observations ... have the power ... to make me feel like utter trash ... And when we had our quality assurance this year it was actually ridiculous that on the first day ... I was like crying, saying 'I don't want to do this job if I'm just adequate; I'm not doing it anymore' ... That's an incredibly ... negative impact on me personally. (Beginner teacher, Project 4)

The use of classroom observation in general and by mentors in particular thus needs to be handled very carefully indeed and (as with all mentoring strategies) adapted to the individual needs, stages of development, and emotional and psychological readiness of mentees. In an ideal world, mentors' observation of mentees' teaching and participation in post-lesson discussion of such teaching should only take place once beginner teachers are psychologically prepared for this, and at the beginner teacher's invitation, since in their vulnerable position it may be difficult for them to say no to more experienced teacher mentors. Having said that, there is a tension here insofar as some mentees with particular dispositions may never actually feel ready to invite mentors to engage in this mentoring and coaching strategy. Hence, while it is vital that mentors are sensitive to mentees' 
Author Accepted Manuscript, 15 April 2016: Hobson, A.J. (2016), “Judgementoring and how to avert it: Introducing ONSIDE Mentoring for beginning teachers" International Journal of Mentoring and Coaching in Education, Vol. 5 No. 2, pp. 87-110.

psychological states and well-being, and should normally take their cue from mentees, in such a scenario, and given their primary responsibility for mentees' PLD and need to ensure that they are provided with a sufficient degree of challenge, it would be beneficial for mentors to encourage mentees' participation in this potentially powerful means of facilitating their PLD.

More generally, the key is for mentors to gain mentees' trust as soon as possible to facilitate mentees' readiness to take full advantage of mentoring support and participate in a wide range of potentially powerful mentoring activities - hence the central importance of the promotion of trust in the ONSIDE Mentoring framework. And in accordance with the principles of ONSIDE Mentoring, any observation and post-lesson discussion must be undertaken in a non-judgemental manner, which is supportive of the beginner teachers' development of critical reflection, autonomy and learnacy, although (again) the post-lesson discussion may sometimes involve relatively directive elements such as providing 'practical advice' or offering potential solutions where the mentor feels that withholding this would be detrimental to the development or well-being of the mentee or potentially harmful to their learners. A particular approach that ONSIDE Mentors might seek to promote, within these parameters, is beginner teachers' participation in 'progressively collaborative teaching' (PCT) (Tomlinson, 1995). PCT involves beginner teachers' engagement in collaborative lesson planning, teaching, and analysis and reflection with a more experienced teacher-mentor, "in a spirit of constructive exploration" and in which mentees assume "more initiative and control" over time (Tomlinson, 1995, p. 51).

Like all mentoring programmes, those based upon the ONSIDE Mentoring framework will be more likely to flourish where efforts are made to provide other identified ingredients of effective mentoring, including the rigorous selection of mentors and matching to mentees, sufficient resourcing to enable mentors and mentees to meet regularly during the working day, and perhaps most importantly - appropriate mentor preparation and development activities. Central to such activities would be a focus on facilitating mentors' understanding of the range of factors potentially affecting beginner teachers' PLD and well-being (Aelterman et al., 2007), and on ways of developing and maintaining trusting relationships (Bryk and Schneider, 2003), as well as on other imperatives of ONSIDE Mentoring. Mentor preparation could also usefully include a 'contextual mentoring audit' (Malderez, 2015), which involves an examination of the extent to which the context is pro- or anti-mentoring in nature, and helps mentors to prepare strategies to shield their mentees from potential impediments to their PLD and well-being. 
Author Accepted Manuscript, 15 April 2016: Hobson, A.J. (2016), “Judgementoring and how to avert it: Introducing ONSIDE Mentoring for beginning teachers" International Journal of Mentoring and Coaching in Education, Vol. 5 No. 2, pp. 87-110.

In offering and commending ONSIDE Mentoring to policymakers, school and college leaders, and mentor trainers and mentors respectively, I anticipate the potential critique (or misunderstanding) that the framework is one-sided and places too much emphasis upon the needs of the beginning teacher at the expense of those of the school or college. I have explained earlier why, as vulnerable learners, beginner teachers need mentors to be on their side. I would also remind the reader that the aim of beginner teacher mentoring, as I see it (and state in the definition of mentoring provided in the introduction to this article), is to support the mentee's learning, development, well-being, and integration into the cultures of the organisation in which they are employed as well as the wider profession. As such, the ONSIDE Mentor will be consciously aware of the needs of the school or college in which the mentee is employed as well as those of the mentee, and will help the beginner teacher develop an understanding of these to assist their integration into the culture of the organisation. In addition, the school or college will undoubtedly benefit from having beginning teachers on their staff who - through the provision and support of ONSIDE Mentors - will be more able to take advantage of opportunities for PLD, more likely to enjoy higher levels of well-being, and thus more likely to be committed to teaching and to the institution that is supporting them. In short, by being on the mentee's side, the ONSIDE Mentor is also on the employing institution's side, and that of the wider profession.

While informed by my own and others' research on beginning teachers, the ONSIDE Mentoring framework is also informed by and wholly consistent with the findings from Project $5-a$ study of 10 exemplary mentoring and coaching programmes across various professions and sectors in six different countries. As such, the framework may be of interest and potentially applicable in other contexts, perhaps especially with respect to early career professionals who, like teachers, may generally be regarded as vulnerable learners. Such possibilities notwithstanding, I look forward optimistically to the potential uptake of ONSIDE Mentoring in schools and colleges, to research and evaluation studies of its impact in those contexts, and perhaps most of all to its contribution to the potential demise of judgementoring.

\section{Acknowledgements}

I am grateful to Angi Malderez, Peter Tomlinson, Linda Searby, Lorraine Harrison, Laura Lunsford and David Stephens for their helpful insights. I also acknowledge the valuable contributions of all my coresearchers on the various underpinning research projects, and to those who supported the projects financially and otherwise, including the Gatsby Charitable Foundation and the (then) Department for 
Author Accepted Manuscript, 15 April 2016: Hobson, A.J. (2016), “Judgementoring and how to avert it: Introducing ONSIDE Mentoring for beginning teachers" International Journal of Mentoring and Coaching in Education, Vol. 5 No. 2, pp. 87-110.

Children, Schools and Families (DCSF), General Teaching Council for England (GTCE) and Training and Development Agency for Schools (TDA).

\section{References}

The 12 publications highlighted with an asterisk are those used for the thematic analysis of previously published research findings from Projects 1-3.

Abell, S. K., Dillon, D. R., Hopkins, C. J., Mclnerney, W. D. and O’Brien, D. G. (1995) 'Somebody to count on': Mentor/intern relationships in a beginning teacher internship program. Teaching and Teacher Education, Vol. 11 No. 2, pp. 173-188.

Adey, K. (1997). First impressions do count: mentoring student teachers. Teacher Development, Vol. 1 No. 1 , pp. 123-133.

Aelterman, A., Engels, N., Van Petegem, K. and Verhaeghe, J. P. (2007) The well-being of teachers in Flanders: the importance of a supportive school culture, Educational Studies, Vol. 33 No. 3, pp. 285297.

Ball, S. J. (2003), "The Teacher's Soul and the Terrors of Performativity", Journal of Education Policy, Vol. 18 No. 2, pp. 215-228.

Beck, C. and Kosnick, C. (2000) Associate teachers in pre-service education: clarifying and enhancing their role, Journal of Education for Teaching, Vol. 26 No. 3, pp. 207-224.

Becker, H.S. (1967) Whose Side Are We On? Social Problems, Vol. 14, pp. 239-47.

BERA (2011) Ethical Guidelines for Educational Research, British Educational Research Association. London.

Boyatzis, R. E., Smith, M. L. and Beveridge, A. J. (2013) Coaching with compassion: Inspiring health, well-being, and development in organizations, The Journal of Applied Behavioral Science, Vol. 49 No. 2, pp. 153-178.

Bradbury, L.U. and Koballa, Jr., T.R., (2008) Borders to cross: Identifying sources of tension in mentor-intern relationships, Teaching and Teacher Education, Vol. 24 No. 8, pp. 2132-2145. Braun, V. and Clarke, V. (2006) Using thematic analysis in psychology. Qualitative Research in Psychology, Vol. 2, 77-101. 
Author Accepted Manuscript, 15 April 2016: Hobson, A.J. (2016), “Judgementoring and how to avert it: Introducing ONSIDE Mentoring for beginning teachers" International Journal of Mentoring and Coaching in Education, Vol. 5 No. 2, pp. 87-110.

Brown, A.L. and Palincsar, A.S. (1989) ‘Guided, Co-operative Learning and Individual Knowledge Acquisition', in LB Resnick (Ed.), Knowing, Learning and Instruction: Essays in Honour of Robert Glaser. Lawrence Erlbaum Associates, Hillsdale NJ.

Brown, A. L., and Palincsar, A. S. (1986). Guided, Cooperative Learning and Individual Knowledge Acquisition. Technical Report No. 372. Retrieved from http://eric.ed.gov/PDFS/ED270738.pdf (accessed 07 March 2016)

Bryk, A. S., and Schneider, B. (2003). Trust in schools: A core resource for school reform. Creating Caring Schools, Vol. 60, pp. 40-45.

Bullough, R. V., Jr. (2005) Being and becoming a mentor: school-based teacher educators and teacher educator identity. Teaching and Teacher Education, Vol. 21, pp. 143-155.

Cameron, M., Whatman. J., Hodgen, E., McLeod, L., Bright, N., Nuttall, J. and Nolan, A. (2014) Evaluation of the Guidelines for induction and mentoring and mentor teachers. New Zealand Council for Educational Research, Wellington.

*Chambers, G.N., Hobson, A.J. and Tracey, L. (2010) "Teaching could be a fantastic job but..." Three stories of student teacher withdrawal from initial teacher preparation programmes in England. Teachers and Teaching: Theory and Practice, Vol. 16 No. 1, pp. 111-129.

Claxton, G. (2004), "Learning is learnable (and we ought to teach it)", in Cassell, J. (Ed.), Ten Years On, The National Commission for Education Report, Bristol, pp. 237-250.

Clutterbuck, D. (1992) Mentoring. Henley: Henley Distance Learning.

Clutterbuck, D.C. (2004), Everyone Needs a Mentor: Fostering talent in your organisation, Chartered Institute of Personnel and Development, London.

Collett, V.S. (2015) The Gradual Increase of Responsibility Model for coaching teachers: Scaffolds for change, International Journal of Mentoring and Coaching in Education, Vol. 4 No. 4, pp. 269-292.

Cornu, R. L. (2005) Peer mentoring: engaging pre-service teachers in mentoring one another, Mentoring and Tutoring, Vol. 13 No. 3, pp. 355-366.

Crasborn, F., Hennisson, P., Brouwer, N., Korthagen, F. and Bergen, T. (2008) Promoting versatility in mentor teachers' use of supervisory skills. Teaching and Teacher Education, Vol. 24, pp. 499-514. Cunningham, B. (2007) All the right features: towards an 'architecture' for mentoring trainee teachers in UK further education colleges, Journal of Education for Teaching, Vol. 33 No. 1, pp. 8397. 
Author Accepted Manuscript, 15 April 2016: Hobson, A.J. (2016), “Judgementoring and how to avert it: Introducing ONSIDE Mentoring for beginning teachers" International Journal of Mentoring and Coaching in Education, Vol. 5 No. 2, pp. 87-110.

Day, C. (2008) Committed for life? Variations in teachers' work, lives and effectiveness, Journal of Educational Change, Vol. 9, pp. 243-260.

Day, C. and Kington, A. (2008) Identity, well-being and effectiveness: the emotional contexts of teaching, Pedagogy, Culture \& Society, Vol. 16, pp. 7-23.

Department for Education (2015), Induction for Newly Qualified Teachers (England): Statutory Guidance for Appropriate Bodies, Headteachers, School Staff and Governing Bodies, Department for Education, London, available at:

https://www.gov.uk/government/uploads/system/uploads/attachment_data/file/458233/Statutory _induction_guidance_for_newly_qualified_teachers.pdf (accessed 15 April 2016).

D'Souza, L.A. (2014),"Bridging the gap for beginning teachers: researcher as mentor", International Journal of Mentoring and Coaching in Education, Vol. 3 No. 2, pp. 171-187.

Duckworth, V. and Maxwell, B. (2015),"Extending the mentor role in initial teacher education: embracing social justice", International Journal of Mentoring and Coaching in Education, Vol. 4 No. 1, pp. 4-20.

Edwards, A. (1998) Mentoring student teachers in primary schools: assisting student teachers to become learners. European Journal of Teacher Education, Vol. 21 No. 1, pp. 47-62.

Edwards, A. and Collison, J. (1996) Mentoring and Developing Practice in Primary Schools. : Open University Press, Buckingham.

Evans, L. and Abbott, I. (1997) Developing as mentors in school-based teacher training. Teacher Development, Vol. 1 No. 1, pp. 135-148.

Feiman-Nemser, S., Parker, M.B. and Zeichner, K. (1993) Are mentor teachers teacher educators?, in McIntyre, D., Hagger, H., and Wilkin, M. (Eds), Mentoring: Perspectives on School-Based Teacher Education, Kogan Page, London, pp. 147-165.

Football Association (2014) Mentoring Scheme Induction Brochure, The FA Professional Game Refereeing Department, London.

Foster, R. (1999) School-based initial teacher training in England and France: trainee teachers' perspectives compared. Mentoring and Tutoring: Partnership in Learning, Vol. 7 No. 2, pp. 131-143. Gold, Y. (1996) Beginner Teacher Support: Attrition, mentoring and induction. In J. Sikula, T.J. Buttery and E. Guyton (Eds), Handbook of Research on Teacher Education, pp. 548-594. Macmillan, New York. 
Author Accepted Manuscript, 15 April 2016: Hobson, A.J. (2016), “Judgementoring and how to avert it: Introducing ONSIDE Mentoring for beginning teachers" International Journal of Mentoring and Coaching in Education, Vol. 5 No. 2, pp. 87-110.

Gouldner, A.W. (1968) The Sociologist as Partisan. The American Sociologist, Vol. 3, pp. 103-116. Greenfield, P.M. (1984) A Theory of the Teacher in the Learning Activities of Everyday Life. In B. Rogoff and J. Lave (Eds.), Everyday Cognition: Its Development in Social Context (pp. 117-138). Harvard University Press, Cambridge, MA.

Hargreaves, A. and Fullan, M. (2000) Mentoring in the New Millennium, Theory into Practice, Vol. 29 No. 1 , pp. 50-56.

Hascher, T., Cocard, Y. and Moser, P. (2004) Forget about theory - practice is all? Student teachers' learning in practicum. Teachers and Teaching: Theory and Practice, Vol. 10 No. 6, pp. 623-637.

Heilbronn, R., Jones, C., Bubb, S. and Totterdell, M. (2002) School-based induction tutors - a challenging role. School Leadership and Management, Vol. 22 No. 4, pp. 371-388.

Hobson, A. J. (2002) Student teachers' perceptions of school-based mentoring in initial teacher training (ITT). Mentoring and Tutoring, Vol. 10 No. 1, pp. 5-20.

*Hobson, A. J. (2009) On being bottom of the pecking order: beginner teachers' perceptions and experiences of support. Teacher Development, Vol. 13 No. 4, pp. 299-320.

*Hobson, A.J. and Malderez, A. (2013) Judgementoring and other threats to realizing the potential of school-based mentoring in teacher education, International Journal of Mentoring and Coaching in Education, Vol. 2 No. 2, pp. 89-108.

*Hobson, A.J. and McIntyre, J. (2013) Teacher fabrication as an impediment to professional learning and development: the external mentor antidote, Oxford Review of Education, Vol. 39 No. 3, pp. 345365.

Hobson, A.J. and Townsend, A.J. (2010) Interviewing as educational research method(s). In: D. Hartas (Ed.) Educational Research and Inquiry: Qualitative and Quantitative Approaches, pp. 223-238. London: Continuum.

Hobson, A. J., Ashby, P. Malderez, A, and Tomlinson, P. D. (2009a) Mentoring beginning teachers: what we know and what we don't. Teaching and Teacher Education, Vol. 25 No. 1, pp. 207-216. Hobson, A.J., Castanheira, P., Doyle, K., Csigás, Z. and Clutterbuck, D. (2016) The Mentoring Across Professions (MAP) Project: What can teacher mentoring learn from international good practice in employee mentoring and coaching? Gatsby Charitable Foundation, London.

*Hobson, A. J., Giannakaki, M. and Chambers, G. N. (2009c) Who withdraws from initial teacher preparation programmes and why? Educational Research, Vol. 51 No. 3, pp. 321-340. 
Author Accepted Manuscript, 15 April 2016: Hobson, A.J. (2016), “Judgementoring and how to avert it: Introducing ONSIDE Mentoring for beginning teachers" International Journal of Mentoring and Coaching in Education, Vol. 5 No. 2, pp. 87-110.

*Hobson, A.J., Malderez, A., Tracey, L., Giannakaki, M.S., Pell, R.G. \& Tomlinson, P.D. (2008) Student teachers' experiences of initial teacher preparation in England: core themes and variation, Research Papers in Education, Vol. 23 No. 4, pp. 407-433.

*Hobson, A. J., Malderez, A., Tracey, L., Homer, M. S., Ashby, P., Mitchell, N., McIntyre, J., Cooper, D., Roper, T., Chambers, G. N. and Tomlinson, P. D. (2009b) Becoming a Teacher: Teachers' Experiences of Initial Teacher Training, Induction and Early Professional Development. Final Report. Department for Children, Schools and Families, London.

*Hobson, A.J., Malderez, A., Tracey, L., Homer, M., Mitchell, N., Biddulph, M., Giannakaki, M.S., Rose, A., Pell, R.G., Chambers, G.N., Roper, T. and Tomlinson, P.D. (2007) Newly Qualified Teachers' experiences of their first year of teaching: Findings from Phase III of the Becoming a Teacher project. Department for Children, Schools and Families, Nottingham.

*Hobson, A.J., Maxwell, B., Stevens, A., Doyle, K. and Malderez, A. (2015) Mentoring and coaching for teachers in the Further Education and Skills Sector in England: full report. Gatsby Charitable Foundation, London. Available at:

http://www.gatsby.org.uk/uploads/education/reports/pdf/mentoring-full-report.pdf

*Hobson, A.J., McIntyre, J., Ashby, P., Hayward, V., Stevens, A. and Malderez, A. (2012) The nature, impact and potential of external mentoring for teachers of physics and other subjects in England: full report. Gatsby Charitable Foundation, London. Available at:

http://www.gatsby.org.uk/ /media/Files/Education/Gatsby\%20\%20Impact\%20of\%20Mentoring Hopkins-Thompson, P. A. (2000) Colleagues helping colleagues: mentoring and coaching. NASSP Bulletin, Vol. 84, No. 617, pp. 29-36.

Huberman, M. (1989) The professional life cycle of teachers. Teachers' College Record, Vol. 91 No.1, pp. 31-57.

Ingersoll, R. and Kralik, J. (2004) The Impact of Mentoring on Teacher Retention: What the Research says. Education Commission of the States, Denver, CO. Available at: http://www.ecs.org/clearinghouse/50/36/5036.htm Jack, A. I., Boyatzis, R. E., Khawaja, M. S., Passarelli, A. M. and Leckie, R. L. (2013) Visioning in the brain: An fMRI study of inspirational coaching and mentoring, Social Neuroscience, Vol. 8 No. 4, pp. 369-384.

Johnson, S.M. and Birkeland, S.E., (2003) Pursuing a "sense of success": New teachers explain their career decisions. American Educational Research Journal, Vol. 40 No. 3, pp. 581-617. 
Author Accepted Manuscript, 15 April 2016: Hobson, A.J. (2016), “Judgementoring and how to avert it: Introducing ONSIDE Mentoring for beginning teachers" International Journal of Mentoring and Coaching in Education, Vol. 5 No. 2, pp. 87-110.

Kelchtermans, G. and Ballet, K., (2002) The micropolitics of teacher induction. A narrativebiographical study on teacher socialisation. Teaching and Teacher Education, Vol. 18 No. 1, pp. 105120.

Kochan, F., Searby, L., George, M.P., Mitchell Edge (2015) Cultural influences in mentoring endeavors: applying the Cultural Framework Analysis Process, International Journal of Mentoring and Coaching in Education, Vol. 4 No. 2, pp. 86-106.

Kourieos, S. (2015) Personal communication, 25.12.2015.

Lee, J.C. and Feng, S. (2007) Mentoring support and the professional development of beginning teachers: a Chinese perspective. Mentoring and Tutoring: Partnership in Learning, Vol. 15 No. 3, pp. 243-263.

Ling, L. (2009) Induction: making the leap, Research in Comparative and International Education, Vol. 4 No. 1, pp. 87-95.

Lejonberg, E., Elstad, E. and Christophersen, K.A. (2015) Mentor education: challenging mentors' beliefs about mentoring, International Journal of Mentoring and Coaching in Education, Vol. 4 No. 2, pp.142-158.

Lindgren, U. (2005) Experiences of beginning teachers in a school-based mentoring programme Sweden. Educational Studies, Vol. 31 No. 3, pp. 251-263.

Lingfield, R. (2012) Professionalism in Further Education: Final report of the Independent Review Panel. London: Department for Business, Innovations and Skills. Available at: www.gov.uk/government/uploads/system/uploads/attachment data/file/34641/12-1198professionalism-in-further-education-final.pdf (accessed 5th April, 2016) Lofthouse, R. and Thomas, U. (2014), Mentoring student teachers; a vulnerable workplace learning practice, International Journal of Mentoring and Coaching in Education, Vol. 3 No. 3, pp. 201-218. Lunsford, L. (2016) Personal communication, 02.02.2016 and 04.03.2016. Maguire, M. (2001) Bullying and the post-graduate secondary school trainee: an English case study, Journal of Education for Teaching, Vol. 27 No. 1, pp. 95-109.

Malderez, A. (2001) New ELT professionals, English Teaching Professional, Vol. 19, pp. 57-58. 
Author Accepted Manuscript, 15 April 2016: Hobson, A.J. (2016), “Judgementoring and how to avert it: Introducing ONSIDE Mentoring for beginning teachers" International Journal of Mentoring and Coaching in Education, Vol. 5 No. 2, pp. 87-110.

Malderez, A. (2015) On Mentoring in Supporting (English) Teacher Learning: Where are we now? In Hollo, D. \& K.Karolyi (Eds), Inspirations in Foreign Language Teaching: Studies in Language Pedagogy and Applied Linguistics in Honour of Peter Medgyes. Pearson, Harlow, pp. 21-32.

Malderez, A. and Bodoczky, C. (1999), Mentor Courses: A Resource Book for Trainer Trainers, Cambridge University Press, Cambridge.

Manning, C. and Hobson, A.J. (forthcoming) Judgemental and developmental mentoring in Further Education Initial Teacher Education in England: Mentor and mentee perspectives.

McIntyre, D. and Hagger, H. (1996) Mentors in Schools: developing the profession of teaching, David Fulton, London.

*McIntyre, J. and Hobson, A.J. (2016) Supporting beginner teacher identity development: external mentors and the third space, Research Papers in Education, Vol. 31 No. 2, pp. 133-158.

Netolicky, D. (2016), "Oil in water": Coaching for professional growth in one Australian school, International Journal of Mentoring and Coaching in Education, 5(2).

Ng, P.T. (2012) "Mentoring and coaching educators in the Singapore education system", International Journal of Mentoring and Coaching in Education, Vol. 1 No. 1, pp. 24-35.

Oberski, I., Ford, K., Higgins, S. and Fisher, P. (1999) The importance of relationships in teacher education. Journal of Education for Teaching, Vol. 25 No. 2, pp. 135-150.

Roehrig, A. D., Bohn, C. M., Turner, J. E. and Pressley, M. (2008) Mentoring beginning primary teachers for exemplary teaching practices. Teaching and Teacher Education, Vol. 24, pp. 684-702.

Rippon, J. H. and Martin, M. (2006) What makes a good induction supporter? Teaching and Teacher Education, Vol. 22, pp. 84-99.

Sahlberg, P. (2010) Rethinking Accountability in a Knowledge Society, Journal of Educational Change, Vol. 11, pp. 45-61.

Schön, D. (1983) The Reflective Practitioner. How professionals think in action, Temple Smith, London.

Searby, L. (2014) The Protégé mentoring mindset: a framework for consideration, International Journal of Mentoring and Coaching in Education, Vol. 3 No. 3, pp.255-276.

Shanks, R., (2014) A study of learners' situational vulnerability: new teachers in Scotland. Education in the North, Vol. 21 Special Issue, pp. 2-20. 
Author Accepted Manuscript, 15 April 2016: Hobson, A.J. (2016), “Judgementoring and how to avert it: Introducing ONSIDE Mentoring for beginning teachers" International Journal of Mentoring and Coaching in Education, Vol. 5 No. 2, pp. 87-110.

Sloboda, J. (1986) Acquiring skill, in: A. Gellatly (Ed.) The Skilful Mind: an introduction to cognitive psychology, Oxford University Press, Milton Keynes, pp.26-38.

Smith, T. and Ingersoll, R. (2004) What are the effects of induction and mentoring on beginning teacher turnover? American Educational Research Journal, Vol. 41 No. 3, pp. 681-714.

Sorensen, P. and Sears, J. (2005) Collaborative practice in initial teacher education: the use of paired subject placements in the school practicum, International Journal of Learning, Vol. 14, pp. 619-631.

Tang, S.Y.F. (2003) Challenge and support: the dynamics of student teachers' professional learning in the field experience. Teaching and Teacher Education Vol. 19, pp. 483-498.

Thornton, K. (2014) Mentors as educational leaders and change agents, International Journal of Mentoring and Coaching in Education, Vol. 3 No. 1, pp. 18-31.

Tomlinson, P. D. (1995). Understanding mentoring: Reflective strategies for school-based teacher preparation. Open University Press, Buckingham.

Tomlinson, P.D. (1998) Teacher education and psychologies of skill, in: D. Shorrocks-Taylor (Ed.) Directions in Educational Psychology, Whurr Publishers, London, pp.85-105.

*Tracey L., Homer, M., Mitchell, N., Malderez, A., Hobson, A. J., Ashby, P. and Pell., G. (2008)

Teachers' Experiences of their Second Year in Post: Findings from Phase IV of the Becoming a Teacher project. Department for Children, Schools and Families, Nottingham.

Ulvik, M. and Sunde, E. (2013), “The impact of mentor education: Does mentor education matter?", Professional Development in Education, Vol. 39 No. 5, pp. 754-70.

Valencic Zuljan, M. and Vogrinc, J. (2007) A mentor's aid in developing the competences of teacher trainees. Educational Studies, Vol. 33 No. 4, pp. 373-384.

Wang, J. (2001) Contexts of mentoring and opportunities for learning to teach: A comparative study of mentoring practice. Teaching and Teacher Education, Vol. 17 No. 1, pp. 51-73.

Wood, D., Bruner, J., and Ross, G. (1976) The role of tutoring in problem solving, Journal of Child Psychology and Child Psychiatry, Vol. 17, pp. 89-100.

Young, J.R., Bullough, R.V., Draper, R.J., Smith, L.K. Erickson, L.B. (2005) Novice teacher growth and personal models of mentoring: choosing compassion over inquiry, Mentoring \& Tutoring:

Partnership in Learning, Vol. 13 No. 2, pp. 169-188. 
Author Accepted Manuscript, 15 April 2016: Hobson, A.J. (2016), "Judgementoring and how to avert it: Introducing ONSIDE Mentoring for beginning teachers" International Journal of Mentoring and Coaching in Education, Vol. 5 No. 2, pp. 87-110.

Yusko, B. and Feiman Nemser, S. (2008) Embracing Contraries: Combining Assistance and Assessment in New Teacher Induction, Teachers College Record, Vol. 110 No. 7, pp. 1-12.

Zachary, L. (2009) The Mentor's Guide. Jossey-Bass, San Francisco. 